SRNL-STI-2013-00039

Revision 0

\title{
Vapor Extraction Well Performance and Recommendations for Transitioning to Passive Extraction at the former DUS-II Site
}

Dennis G. Jackson

Jay V. Noonkester

Brian B. Looney

March 2013

Savannah River National Laboratory Savannah River Nuclear Solutions, LLC Aiken, SC 29808

Prepared for the U.S. Department of Energy under

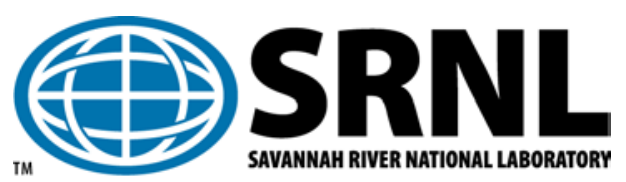
contract number DE-AC09-08SR22470. 
SRNL-STI-2013-00039

Revision 0

\section{DISCLAIMER}

This work was prepared under an agreement with and funded by the U.S. Government. Neither the U.S. Government or its employees, nor any of its contractors, subcontractors or their employees, makes any express or implied:

1. warranty or assumes any legal liability for the accuracy, completeness, or for the use or results of such use of any information, product, or process disclosed; or

2. representation that such use or results of such use would not infringe privately owned rights; or

3. endorsement or recommendation of any specifically identified commercial product, process, or service.

Any views and opinions of authors expressed in this work do not necessarily state or reflect those of the United States Government, or its contractors, or subcontractors.

This document was prepared in conjunction with work accomplished under Contract No. DE-AC09-08SR22470 with the U. S. Department of Energy.

\section{Printed in the United States of America \\ Prepared for U.S. Department of Energy}


SRNL-STI-2013-00039

Revision 0

\section{EXECUTIVE SUMMARY}

The use of steam injection and vapor extraction at the M-Area Settling Basin has removed a significant amount of mass from the subsurface. The overall deployment of dynamic underground stripping (DUS) has been highly effective; however, based upon observations from vapor extraction wells, sufficient mass remains to continue vapor extraction from the subsurface. Vapor extraction will take advantage of the thermal conditions that currently exist at the site because volatile organics can be readily removed from the vapor phase under elevated temperature conditions.

This investigation evaluated mass extraction rate from individual wells associated with the Western Sector Treatment System (formerly known as the DUS-II project). This was critical since each individual well can have a radius of influence in excess of $100-\mathrm{ft}$ when operating using an active extraction system. Future soil vapor extraction should use the existing active extraction system, supplemented with deployment of passive extraction where appropriate. The analysis of mass extraction rates resulted in the grouping of the existing extraction wells as following:

1. Wells with active extraction rates greater than 1.0 pound per day $(\mathrm{n}=10$ including horizontal well VEW-22),

2. Wells with active extraction rates between 0.1 and 1.0 pound per day $(n=11)$, and

3. Wells with active extraction rates below 0.1 pound per day $(n=10)$.

While subsurface temperatures remain elevated the active system should use the nine (9) vapor extraction wells identified in Group 1 along with the horizontal well VEW-22A to maximize extraction rates. Operations should include increased monitoring at the wellhead to allow periodic assessment of well performance. The active system should be augmented with the deployment of passive MicroBlower ${ }^{\mathrm{TM}}$ type extraction units at the eleven (11) extraction wells associated with Group 2. Due to the well configuration, high capacity (24-Volt or greater) MicroBlower ${ }^{\mathrm{TM}}$ systems should be used in the deployment. The analysis identified ten (10) vapor extraction wells that are no longer viable for either active or passive vapor extraction. While vapor temperatures from these ten (10) wells are elevated, the vapor concentrations are low, generally undetectable. As subsurface temperatures continue to decrease, vapor concentrations at these ten (10) wells will decline. A total of eleven (11) vapor extraction wells are identified for abandonment. The basis for abandonment considered performance as a vapor extraction well, current operational status, as well as anticipated needs for groundwater extraction.

With the transition from active to passive, routine monitoring of conditions at the well head becomes important for determining performance. 


\section{TABLE OF CONTENTS}

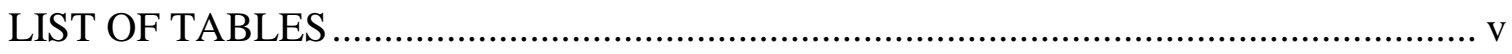

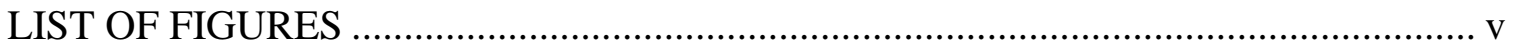

LIST OF ACRONYMS ....................................................................................... vi

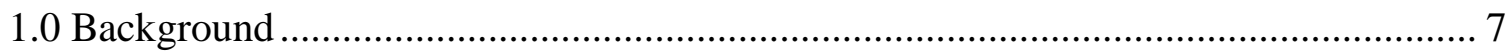

1.1 Soil Vapor Extraction Well Testing - June 2012 ............................................ 8

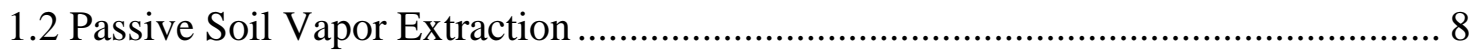

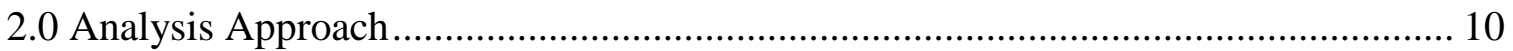

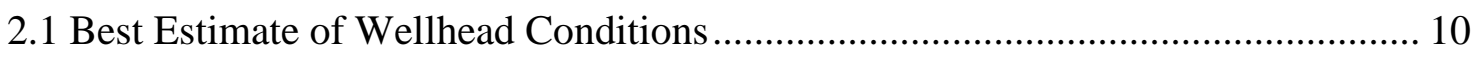

2.2 Mass Extraction Using the Active System ..................................................... 10

2.3 Evaluate Extraction Rate Data and Prioritize Wells for Active Extraction............. 10

2.4 Estimate Well Performance Using MicroBlower ${ }^{\mathrm{TM}}$ Technology ........................... 11

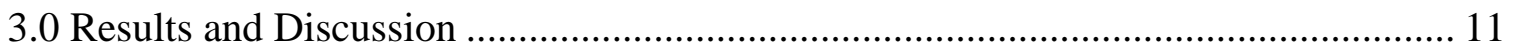

3.1 Best Estimate of Wellhead Conditions ............................................................... 11

3.2 Mass Flow Rate Using the Active Extraction System........................................ 11

3.3 Evaluate Extraction Flow Data and Prioritize Wells for Active Extraction............ 12

3.4 Estimate of Well Performance using MicroBlower ${ }^{\mathrm{TM}}$ Technology ........................ 13

3.5 Wells that are Recommended to be Removed from Service and Abandoned......... 13

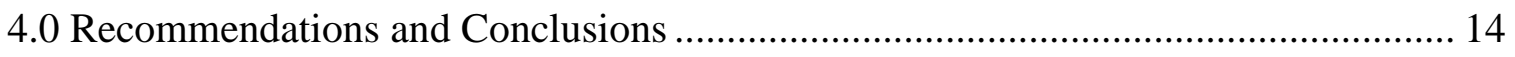

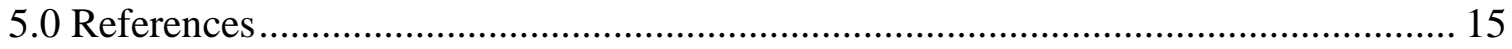

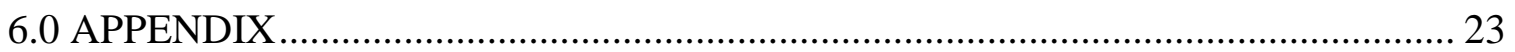


SRNL-STI-2013-00039

Revision 0

\section{LIST OF TABLES}

Table 1: Vapor Extraction Wells and Construction Details Used During the Dynamic Underground Stripping Demonstration at the M-Area Settling Basin 17

Table 2: Identification of Vapor Extraction Wells in Each Parcel of the WSTS 18

Table 3: Extraction Wells and Data Used to Estimate Flow Rates using Inverse Distance Weighting Methods 18

Table 4: Best Estimate of Vapor Conditions from DUS-II Vapor Extraction Wells ${ }^{1}$...... 19

Table 5: Estimated Extraction Rate of Individual Vapor Extraction Wells at MASB ${ }^{1} \ldots .20$

Table 6: Groupings of Extraction Wells Based on Extraction Rates.............................. 21

Table 7: Estimated Performance of Group 2 Vapor Extraction Wells Using

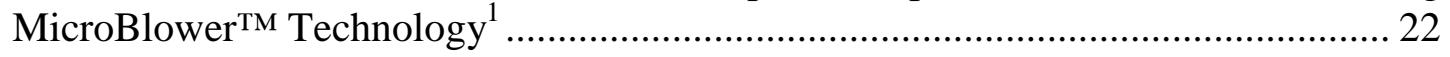

Table 8: Vapor Extraction Wells that are Recemmended for Abandonment $(n=11)$....... 22

\section{LIST OF FIGURES}

Figure 1: Location of Parcels and Soil Vapor Extraction Wells Near the MASB............ 16 
SRNL-STI-2013-00039

Revision 0

\section{LIST OF ACRONYMS}

AC

AM

ASVE

BGS

C-DCE

$\mathrm{CCL}_{4}$

$\mathrm{CHCL}_{3}$

$\mathrm{CH}_{4}$

$\mathrm{CO}_{2}$

DC

DNAPL

DUS

Hp

inHg

ML

MASB

PCE

PM

PPMV

RCRA

SCDHEC

SCFM

SRNL

SRS

SVE

SVEU

TCA

TCE

VEW

VOC

WSTS
Alternating Current

Ante Meridian (Latin = "before midday")

Active Soil Vapor Extraction

Below Ground Surface

cis-Dichloroethane

Carbon Tetrachloride

Chloroform

Methane

Carbon Dioxide

Direct Current

Dense non-Aqueous Phase Liquid

Dynamic Underground Stripping

Horsepower

Inches of Mercury

Milliliter

M-Area Settling Basin

Perchloroethylene

Post Meridian (Latin = "after midday")

Parts per Million Vapor

Resource Conservation and Recovery Act

South Carolina Department Health and Environmental Control

Standard Cubic Feet per Minute

Savannah River National Laboratory

Savannah River Site

Soil Vapor Extraction

Soil Vapor Extraction Unit

$1,1,1$, Trichloroethane

Trichloroethylene

Vapor Extraction Well

Volatile Organic Compound

Western Sector Treatment System 
SRNL-STI-2013-00039

Revision 0

\subsection{Background}

In August 2005, the Savannah River Site (SRS) began operation of the Western Sector Dynamic Underground Stripping (DUS) treatment unit as a technology demonstration project approved by the South Carolina Department of Health and Environmental Control (SCDHEC) under an Industrial Wastewater treatment permit. This facility is a part of the ongoing Resource Conservation and Recovery Act (RCRA) corrective action to support remediation of vadose zone and water table contamination adjacent to the M-Area Settling Basin (MASB).

Through the end of fiscal year 2012 (i.e. September 2012) the Western Sector DUS unit had removed over 450,000 pounds of volatile organic compounds (VOCs). Since steam injection was completed on September 17, 2009 SRS has continued operation of the soil vapor extraction (SVE) and the groundwater remediation portions of the process. This continued operation will exploit the increase in vapor pressure associated with higher temperatures that will enhance removal of residual solvents. The SVE and the groundwater remediation portions of the Western Sector DUS have been designated the Western Sector Treatment System (WSTS) (SRNS, 2012).

The WSTS has three soil vapor extraction units (SVEUs) that were permitted as part of the original permit application for the DUS system (WSRC-RP-2002-4083). The units are also part of Savannah River Site's Title V Part 70 Air Quality Permit (TV-0080-0041). On October 25, 2012, SRS submitted an operational flexibility request to the SCDHEC to remove two of the SVEUs from the Western Sector DUS Extraction System. During active steam injection the maximum vapor extraction capability from the three combined SVEUs was approximately 5,050 standard cubic feet per minute (scfm) at 12 inches of mercury (inHg). The actual combined extraction flow capacity from the 34 extraction wells was less than 3,000 scfm and flow rates during normal operations varied depending on the SVEU configurations and the number of extraction wells in service (Kanzleiter 2008).

The vapor extraction wells consist of both angled and vertical extraction wells positioned to remove the vapors generated from the heating of the subsurface by the steam injection wells. Of the 34 wells, 15 are vertical, 18 are angled, and one is horizontal. The angled wells, with angles ranging from $25^{\circ}$ to $70^{\circ}$ from horizontal, are used to extract contaminated vapors from under the MASB. Vertical vapor extraction wells are identified by an " $F$ " suffix on the well number and angled vapor extraction wells are identified by an "A" suffix on the well number. Well screen lengths are shown in Table 1 and the distribution of the vapor extraction wells are shown in Figure 1. Table 2 identifies the location of the vapor extraction wells in each parcel. The horizontal extraction well (VEW-22A) was installed beneath the MASB with a $300 \mathrm{ft}$ screen at a maximum depth of 56 feet below ground surface (bgs). Directional drilling was used to drill the pilot hole for this well (Kanzleiter 2008).

The remediation at the MASB utilized a parcel treatment strategy to provide a phased approach to operations. The target remediation zone was divided into four parcels as illustrated in Figure 1. During operations these parcels were used to optimize the use of steam capacity and the removal of contaminants to meet the Air Quality Control permit limits. 
Within the A/M Area, the shutdown criterion for active SVE system is based upon the removal of 40 pounds per week or less of total VOCs at a nominal rate of $800 \mathrm{scfm}$. This criterion was established based upon heuristic leaching analysis using traditional SVE. The basis of which was extraction of a single unit that was connected to 4 to 6 vapor extraction wells. The 40 pounds per week criterion does not consider the effects of temperature. During steaming activities at the Western Sector DUS, a significant investment was made to increase the temperature of the vadose zone to temperatures in excess of $212^{\circ} \mathrm{F}\left(100^{\circ} \mathrm{C}\right)$. It is important to capitalize on this investment and maximize removal from the vadose zone while the temperature is elevated. Since volatile organics can be readily removed from the vapor phase under elevated temperature conditions, continued vapor extraction will take advantage of the thermal conditions that currently exist at the site.

\subsection{Soil Vapor Extraction Well Testing - June 2012}

In June of 2012 the soil gas samples were collected from the vapor extraction well the DUS II site and analyzed for target constituents (Noonkester et al. 2012b). The primary objective was to determine which wells should continue to be used for active SVE with a secondary objective to identify extraction wells that can be transitioned from active to passive treatment systems. These results will be important in directing future SVE operations at the WSTS. These results indicated that the highest levels of VOC contamination are in Parcel 1 with lesser amounts in the other three parcels. Several VOC compounds were detected with tetrachloroethylene (PCE) making up the majority of the contaminant with lesser amounts of trichloroethylene (TCE). Most soil gas concentrations of PCE ranged from 0 to 60 parts per million volume (ppmv) with one well (VEW-22A) as high as 200 ppmv.

The June 2012 characterization involved performing SVE tests on approximately four (4) wells at a time by extracting from the wells using the active SVE system for a 24-hour period. During the test period the targeted wells were valved open to the ASVE system to perform purging. Each 24-hour test period started at approximately 10:00 AM each day. During the test period vapor samples were collected at each wellhead using a portable vacuum pump. A total of five sets of samples were collected during the 24-hour testing period. Soil gas samples were collected in both $20 \mathrm{ml}$ headspace vials by using the headspace vial/ziploc method and in Tedlar ${ }^{\circledR}$ bags. The $20 \mathrm{ml}$ vials were analyzed on a gas chromatograph at the Savannah River National Laboratory (SRNL) and the following compounds were reported: PCE, TCE, 1,1,1trichloroethane (TCA), cis-dichloroethane (C-DCE), carbon tetrachloride $\left(\mathrm{CCL}_{4}\right)$, chloroform $\left(\mathrm{CHCL}_{3}\right)$, and methane $\left(\mathrm{CH}_{4}\right)$. Other constituents of operational interest to the operation of the WSTS, i.e. mercury and polychlorinated biphenyl, were not within the scope of this investigation.

Thirty-one of the thirty-four SVE wells were successfully tested. The wells that were not evaluated were VEW-13A, VEW-16F, and VEW-32F. VEW-13A was producing excessive amounts of condensate which oversaturated samples making them un-analyzable. VEW-16F and VEW-32F had been capped off and were no longer connected to the extraction system.

\subsection{Passive Soil Vapor Extraction}

Passive SVE is an enhanced attenuation approach that removes volatile contaminants from the vadose zone. The MicroBlowerTM Sustainable Soil Vapor Extraction System (US Patent No. $\# 6,971,820)$ is a cost-effective device specifically designed for remediation of organic 
compounds in the vadose zone. The system is powered by a low-voltage brushless blower, powered by a sustainable direct current (DC) power source consisting of batteries charged by a photovoltaic panel. MicroBlowers ${ }^{\mathrm{TM}}$ are appropriate as an interim, remedial, or polishing strategy. The technology has been deployed at the SRS in support of cleanup initiatives since 2002.

The original design consisted of a 12-volt system that was powered by a 40 -watt photovoltaic panel. This design was effective but only operated during times of sunlight. The second generation incorporates a 24 -volt system powered by a battery bank and a 160 -watt photovoltaic panel. The second generation system was sized so it would have enough stored power to operate continuously for three consecutive days of low-sunlight conditions (i.e., cloudy weather).

A MicroBlower ${ }^{\mathrm{TM}}$ uses a small, low-power vacuum blower to extract or inject gases into the subsurface for remediation. Because the components of the system have a long operating life, the system is useful for long-term cleanup operations, particularly where mass transfer limits the rate of remediation. A MicroBlower ${ }^{\mathrm{TM}}$ is effective in targeting small source zones where conventional SVE is too excessive.

The MicroBlower ${ }^{\mathrm{TM}}$ is designed to operate 24 hours a day and is capable of generating a maximum vacuum of 10 inches of water and a maximum flow rate of $18 \mathrm{scfm}$. MicroBlowers ${ }^{\mathrm{TM}}$ are inexpensive to purchase, operate, and maintain. MicroBlower ${ }^{\mathrm{TM}}$ was originally designed to be mobile and operate in isolated areas with no infrastructure but can easily operate from an alternating current (AC) power source by using an AC/DC converter. The MicroBlower ${ }^{\mathrm{TM}}$ is ideal for remote locations with limited or no ancillary infrastructure. By using renewable sources of energy, the MicroBlower ${ }^{\mathrm{TM}}$ eliminates the need for generators and fuel storage at remote locations.

MicroBlowers ${ }^{\mathrm{TM}}$ require only between 20 and 40 watts and can be powered using photovoltaic panels, wind generators, a 24-volt battery bank recharged by either photovoltaic panels or wind generators, or 24-volt power from a 110-to-24-volt transformer. Using a 110-to-24-volt transformer, operating electrical costs for a MicroBlower ${ }^{\mathrm{TM}}$ is less than ten cents per day (based on an electrical cost of $\$ 0.10 /$ kilowatt-hour).

MicroBlower ${ }^{\mathrm{TM}}$ offers the advantage of a reduced carbon footprint and low operating and maintenance expenses. MicroBlowers ${ }^{\mathrm{TM}}$ provide a better ratio of contaminant removed to carbon dioxide $\left(\mathrm{CO}_{2}\right)$ emissions during remediation activities compared to conventional remediation tools. Power generation for a conventional SVE system (25 hp) operating 60 percent of the time emits approximately 131,176 pounds of $\mathrm{CO}_{2}$ per year. 


\subsection{Analysis Approach}

In this investigation the results from June of 2012 (Noonkester et al. 2012b) are used to prioritize the vapor extraction wells associated with the MASB in regards to 1) primary use for active SVE, 2) component of a sustainable vapor extraction system using passive technology, or 3) minimal mass removal rates. The analysis involved:

- Establishing the best estimate of flow conditions at each wellhead,

- Determining the mass flow rate for each well using the active system,

- Evaluate extraction flow data and prioritizing wells for active extraction, and

- Estimating individual well performance using MicroBlower ${ }^{\mathrm{TM}}$ technology.

\subsection{Best Estimate of Wellhead Conditions}

In a previous investigation the active vapor extraction system was used to collect multiple vapor samples from each well over a minimum 24-hour period (Noonkester et al, 2012b). These samples were then analyzed for organic constituents of interest. In addition the investigation also recorded temperature and flow parameters at the well head (see Appendix A and B, Noonkester et al., 2012b).

In the current investigation these observations are used to provide a best estimate of conditions at each wellhead. For most wells this involved identifying steady conditions following the extraction of multiple gas volumes from the wellbore. Flow, temperature, and pressure conditions were measured with existing, installed, process instrumentation when available. During pre-test work planning it was discovered that several of the installed flow meters were inoperable. For these wells an insert style mass flow meter was used to measure flow.

\subsection{Mass Extraction Using the Active System}

Using the best estimate of well head conditions the mass extraction rate for each well was determined. This calculation involved the conversion of the vapor concentrations reported in ppmv to mass per unit volume at the gas collection temperature. This conversion utilizes the following relationship: 
SRNL-STI-2013-00039

Revision 0

\subsection{Estimate Well Performance Using MicroBlower ${ }^{\mathrm{TM}}$ Technology}

Wells that are identified as candidates for transition to passive are further analyzed and estimates of performance under passive extraction are performed. This utilizes earlier observations on the performance of these systems within A/M Area (Noonkester et al., 2012a).

\subsection{Results and Discussion}

\subsection{Best Estimate of Wellhead Conditions}

Using the observations reported by Noonkester et al. (2012b) the best estimate values of temperature, flow rate, and concentration were identified. These observations are presented in Table 4 and were generally derived based upon the average of the later observations reported (i.e. at times greater than 20-hrs). In establishing the best estimate values for flow it was observed that when flow rates for both the installed flow equipment and insert flow meter were reported, there was poor agreement between the two sources. Because flow and concentration are both first order variables in determining mass flow rate the uncertainties associated with each of these variables have equal influence in the analysis. Since the objective of the investigation is an internal ranking between wells. In identifying the best estimate of flow, the observation from the insert flow meter was preferred over those of the installed flow equipment.

Flow rate data was not available for wells VEW-21F, VEW-23F, and VEW-31F. The flow from these wells was estimated based upon flow observations from wells of similar construction. All three of the wells with missing flow data are 6-inch vertical wells having a 120-foot long screen zone, essentially targeting the vadose zone section of the subsurface. At the DUS-II site flow rate information was reported (Noonkesteret al., 2012b) from ten (10) extraction wells having similar configuration. As shown in Table 3 the flow rate from these wells ranged between 82 and 371 cubic feet per minute $(\mathrm{cfm})$. This data was used to estimate the flow rates at VEW-21F, VEW23F, and VEW-31F. The flow rates were estimated for each point using an inverse distance weighting method (Isaaks and Srivastave 1989). This technique provides an estimate of an unknown parameter based upon observations at surrounding locations. The method improves upon simple arithmetic averaging by giving more weight to observations from closer samples and less to those farther away.

As presented in Table 4 the extracted gas temperature ranged between $87^{\circ} \mathrm{F}$ and $158^{\circ} \mathrm{F}\left(30^{\circ} \mathrm{C}\right.$ $70^{\circ} \mathrm{C}$ ) and the average flow rate ranged between 4 and $434 \mathrm{cfm}$. The minimum flow was observed at VEW-19A located in Parcel 3 and the maximum flow was observed in Parcel 1 at VEW-25A. The highest vapor concentrations $\left(\mathrm{PCE}=547.55 \mathrm{mg} / \mathrm{m}^{3}\right.$ and $\mathrm{TCE}=326.82$ $\mathrm{mg} / \mathrm{m}^{3}$ )were reported from VEW-22A, the horizontal well that has a long, extensive horizontal screen zone beneath the MASB.

\subsection{Mass Flow Rate Using the Active Extraction System}

Using the best estimate values of concentration and flow that are presented in Table 4, the mass flow rate of organic constituents PCE, TCE, and TCA was calculated as the product of the vapor concentration and the volume flow rate and reported as pounds per day. These values were then summed to estimate the total VOC removal rate for each well using the active extraction system. These results are presented Table 5 . Table 5 also identifies the intergroup ranking of the various wells. As indicated by this analysis well VEW-22A provides the greatest extraction rate of VOCs 
from the subsurface. This is most likely attributed to the unique construction of this well with respect to other wells in the analysis. VEW-22A is a horizontal well with a 300 -foot long screen length. This is significantly greater than the other extraction wells that either incorporate vertical screens or shorter angled screened zones.

\subsection{Evaluate Extraction Flow Data and Prioritize Wells for Active Extraction}

By examining the range and order of magnitude of the mass extraction rate data that is presented in Table 5, the following groups of extraction wells are identified:

1. Wells with extraction rates greater than 1.0 pound per day (9 wells + VEW-22A),

2. Wells with extraction rates between 0.1 and 1.0 pound per day (11 wells), and

3. Wells with extraction rates below 0.1 pound per day (10 wells).

Table 6 presents this grouping sorted by the mass extraction rate and identifies wells within each group. To maximize future performance of the active vapor extraction system those wells with the highest extraction rates should be operated. This set includes the nine vertical/angled extraction wells identified in Group 1 (Table 6) and horizontal well VEW-22A. All of these wells have individual extraction rates greater than 1.0 pound per day using the active vapor extraction system. As operations progress the concentration and gas temperature will decease at the wellhead. Therefore, the operational paradigm should incorporate routine monitoring of vapor concentration and temperature at the wellhead during periods of active extraction. This will allow the future evaluation of wellhead specific extraction rates. These rates can then be contrasted against those presented in this report to evaluate performance of individual extraction wells. In addition routine vacuum measurements should be periodically reported using adjacent, idle wells. This information will provide valuable insight on the effected zone associated with operation of each well.

Group 2 includes those wells with extraction rates between 0.1 and 1.0 pound per day using the active extraction system. Historically wells with this low level of performance would have been recommended as a source of make-up air to prevent exceeding air emission thresholds. However, under the planned operating scheme of one extraction unit serviced by 3 to 4 extraction wells, there is a surplus of wells in Group 1 available. Due to the number of wells in Group 1 that are available for active extraction, the wells identified in Group 2 are not necessary for future active SVE. These wells would be ideal candidates to consider for transitioning operation from an active to a passive vapor extraction system. The performance of these wells under passive SVE is discussed in Section (3.4).

Group 3 contains ten (10) vapor extraction wells whose performance under active extraction was less than 0.1 pounds per day. These wells have minimal performance under active vapor extraction and are not recommended as part of an active or passive extraction system. It is noted that extraction wells VEW-21F and VEW-33F are dual phase extraction wells and have the capability to remove groundwater from the saturated zone as well as vapor from the vadose zone. These wells provide a unique capability and should be maintained until a complete assessment of groundwater is performed. Regardless of short-term disposition as vent wells, with the exception of VEW-21F and VEW-33F the Group 3 wells can likely be the first set of vapor extraction wells to be abandoned. 


\subsection{Estimate of Well Performance using MicroBlower ${ }^{\mathrm{TM}}$ Technology}

In Section 3.3 eleven (11) vapor extraction wells were identified as potential candidates for use as passive vapor extraction wells. The majority of these wells are located in Parcel 2 with VEW15A located in Parcel 3, VEW-23F located in Parcel 4, and VEW-34F located in Parcel 1. In comparison to other MicroBlower ${ }^{\mathrm{TM}}$ deployments (Noonkester et al., 2012a) these wells have larger diameters (4 and 6-in) and have screen lengths ranging from 30 to 120 feet. These parameters couple to create large well bore volumes that facilitate the use of the highest capacity systems available.

The 24-volt version of the MicroBlower is designed to operate 24 hours a day and is capable of generating a maximum vacuum of 10 inches of water and a maximum flow rate of $18 \mathrm{scfm}$ (Noonkester et al., 2012a). The actual performance will vary depending upon the pressure and flow characteristics of each well; a reasonable performance of $10 \mathrm{cfm}$ should be expected from these wells. Table 7 presents estimated extraction rates for the Group 2 wells using 24-Volt MicroBlowers ${ }^{\mathrm{TM}}$ operating at $10 \mathrm{cfm}$. If equipped with MicroBlowers ${ }^{\mathrm{TM}}$, collectively the Group 2 wells are estimated to provide an additional 40 pounds per year of mass extraction.

An important aspect for application of passive vapor extraction is the role that ongoing active extraction will have on the performance of the MicroBlower ${ }^{\mathrm{TM}}$. A MicroBlower ${ }^{\mathrm{TM}}$ that is installed within the zone of influence of an active extraction system will likely be ineffective. This would be due to the drawdown associated with active extraction at a nearby extraction well. Within A/M Area the radius of capture of active systems is reported to be on the order of 100 to 300 feet for extraction rates of $150 \mathrm{scfm}$ (WSRC, 1997). These observations were reported for vapor extraction wells associated with the former 782-5M SVEU that was located just north of the MASB along the abandoned process sewer line. In contrast, it was recently reported that 24volt Microblowers have a radius of influence of 41 feet when operating at $10.3 \mathrm{scfm}$ (Noonkester et al., 2012a). The later investigation was performed between the 782-5M SVEU and the WSTS location. The increased pressure differential associated with the active system may result in damage to the MicroBlower ${ }^{\mathrm{TM}}$. The implementation of the passive system at each wellhead should consider engineering or operational controls to isolate the system as necessary. An example of an operational control would be a manual isolation valve that would be closed when the vacuum pressure in the subsurface exceeded the pressure capacity of the MicroBlower ${ }^{\mathrm{TM}}$. This concept could be automated using a pressure switch and relay to control the power to the MicroBlower ${ }^{\mathrm{TM}}$.

A final consideration involves temperature of the extracted gas. Currently these temperatures are generally in the range of $100^{\circ} \mathrm{F}\left(38^{\circ} \mathrm{C}\right)$ to $150^{\circ} \mathrm{F}\left(65^{\circ} \mathrm{C}\right)$. This is near the upper limit of the operating range for the blower in the MicroBlower ${ }^{\mathrm{TM}}$. While vapor temperatures are anticipated to decrease, the elevated temperatures may decrease service life.

\subsection{Wells that are Recommended to be Removed from Service and Abandoned}

The mass extraction analysis presented in Table 7 identified ten (10) wells that have a VOC extraction rate less than 0.1 pounds per day. In addition, based upon 2009 concentration data well VEW-13A is identified as having poor extraction performance. Furthermore, during testing in the summer of 2012 vapor extraction wells VEW-16F and VEW-32F were identified as no 
longer being connected to the active extraction system. There are a total of thirteen (13) vapor extraction wells that should be considered for abandonment.

The selection of VEW-13A for abandonment is based upon concentration data from 2009 that is presented in Appendix A. As shown in Appendix A, well VEW-13A had a total VOC concentration (PCE + TCE + TCA) of 5 ppm. This level ranks the well 26th of the 29 wells that had concentration data reported.

While extraction wells VEW-21F and VEW-33F had vapor extraction rates below 0.1 pounds per day, these two wells are dual designed for phase extraction. This allows extraction of both groundwater and soil vapor. Since these wells have groundwater extraction capacity abandonment should be deferred until a groundwater assessment of the former DUS site is performed.

With these considerations there are a total of eleven (11) vapor extraction wells that are recommended for abandonment. These wells are presented in Table 8 along with rationale for identifying the wells for abandonment.

\subsection{Recommendations and Conclusions}

The use of steam injection and vapor extraction at the MASB has removed a significant amount of mass from the subsurface. Overall the deployment of DUS has been highly effective; however, based upon observations from vapor extraction wells sufficient mass remains to continue vapor extraction from the subsurface. This will take advantage of the thermal conditions that currently exist at the site. Volatile organics can be readily removed from the vapor phase under elevated temperature conditions.

Future SVE should use existing active extraction system along with passive extraction technology. While subsurface temperatures remain elevated the active system should use vapor extraction wells identified in Group 1 along with VEW-22A to maximum extraction rate. Operations should include increased monitoring at the wellhead to allow periodic assessment of well performance. The active system should be augmented with the deployment of passive MicroBlower ${ }^{\mathrm{TM}}$ type extraction units at extraction wells associated with Group 2. Due to the well configuration, high capacity (24-Volt or greater) Microblower systems should be used in the deployment. The analysis further identified a series of vapor extraction wells that are no longer viable for either active or passive vapor extraction (i.e. Group 3 wells). While vapor temperatures from these wells are elevated, observed concentrations are low, often undetectable. As subsurface conditions continue to cool, the concentrations at these wells will also decrease due to decreases in vapor pressure, which is strongly temperature dependent. During the investigation a total of eleven (11) vapor extraction wells are identified for abandonment (Table 8) along with as well as the rational for abandonment. 
SRNL-STI-2013-00039

Revision 0

\subsection{References}

Isaaks, E. H. and R. M. Srivastave (1989). An Introduction to Applied Geostatistics. Oxford University Press, New York, New York.

Kanzleiter, J.P. (2008). Western Sector Dynamic Underground Stripping Remediation System at the M-Area Settling Basin, Facility Technical Brief. ERD-EN-2004-0215, Revision 1, January 3, 2008.

Noonkester, J.V., B.D. Riha, G.M. Birk, and B.H. Rambo (2012a). "Demonstration of Microblower Technology for Sustainable Soil Vapor Extraction: Case Studies at the Savannah River Site, South Carolina,” Remediation, Autumn 2012, DOI: 10.1002/rem.

Noonkester, J. V., D. G. Jackson, W. E. Jones, W. K. Hyde, J. L. Kohn, and R. Walker (2012b). DUS II Soil Gas Sampling and Air Injection Test Results, SRNL-STI-2012-00449, September 2012, Savannah River National Laboratory, Aiken, SC 29808.

WSRC (1997). Extent of A/M Area Vadose Zone Contamination, Monitoring, and Corrective Action, WSRC-RP-97-0109, March 1997, Westinghouse Savannah River Company, Aiken, SC 29808.

WSRC (1998). A/M Area Vadose Zone Monitoring Plan, WSRC-RP-98-00146, March 1998, Westinghouse Savannah River Company, Aiken, SC 29808.

SRNS (2012). Western Sector Treatment System (WSTS) Project Description, SRNS-RP-201200230, Revision 0, April 2012. Savannah River Nuclear Solutions, LLC, Aiken, SC 29808. 


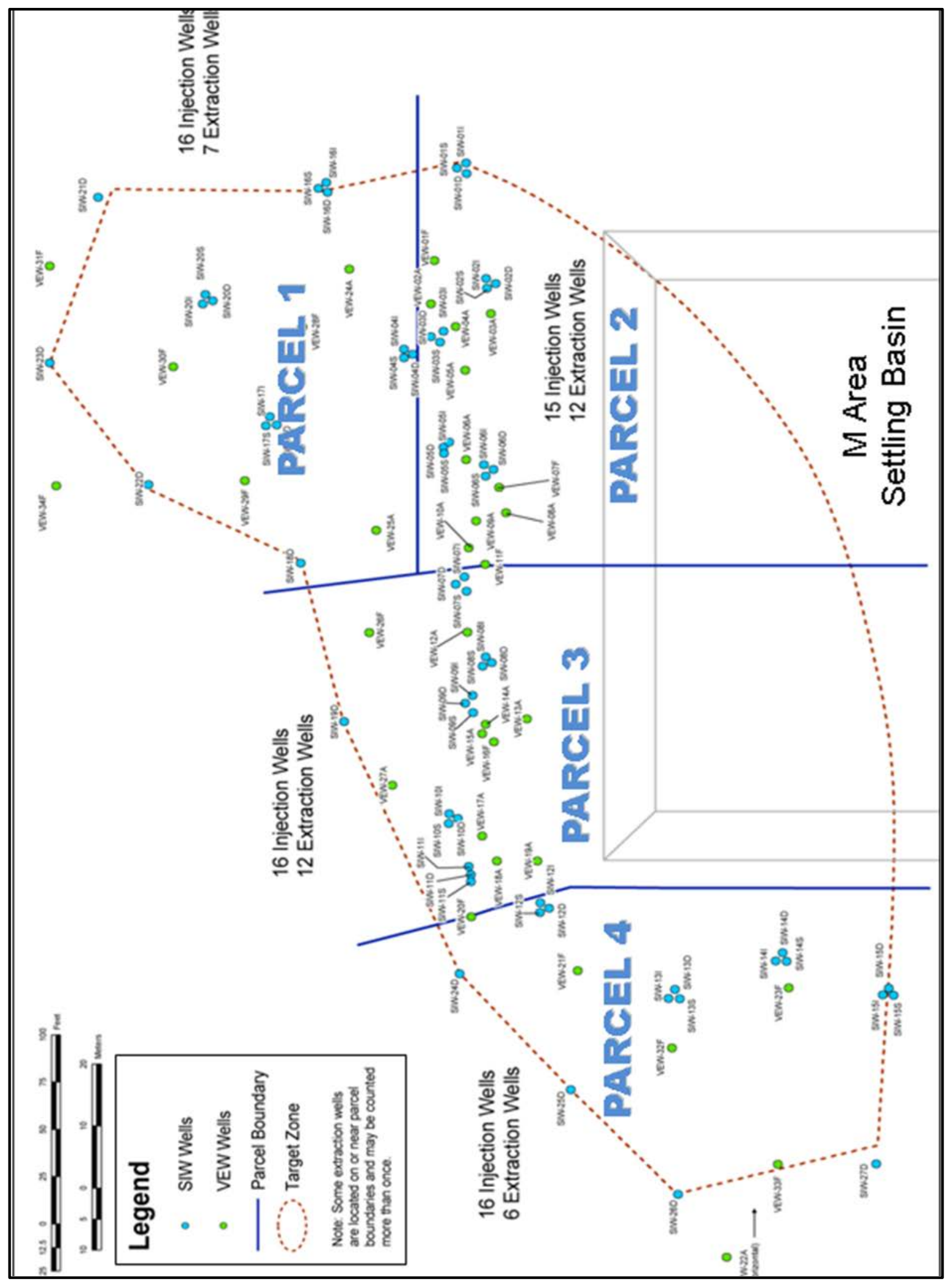

Figure 1: Location of Parcels and Soil Vapor Extraction Wells Near the MASB 
SRNL-STI-2013-00039

Revision 0

Table 1: Vapor Extraction Wells and Construction Details Used During the Dynamic Underground Stripping Demonstration at the M-Area Settling Basin

\begin{tabular}{|c|c|c|c|c|c|c|c|}
\hline Well ID & Angle $\left(^{\circ}\right)$ & $\begin{array}{l}\text { Dia. } \\
\text { (in.) }\end{array}$ & $\begin{array}{c}\text { Depth } \\
\text { (ft. bgs) }\end{array}$ & $\begin{array}{c}\text { Installed } \\
\text { Date }\end{array}$ & $\begin{array}{l}\text { Bottom } \\
\text { Screen } \\
\text { (ft bgs) }\end{array}$ & $\begin{array}{c}\text { Top } \\
\text { Screen } \\
\text { (ft bgs) }\end{array}$ & $\begin{array}{c}\text { Top } \\
\text { Sand } \\
\text { Pack } \\
\text { (ft bgs) }\end{array}$ \\
\hline VEW-01F & 90 & 6 & 157.0 & $8 / 6 / 03$ & 152.6 & 32.6 & 30.0 \\
\hline VEW-02A & 50 & 4 & 203.0 & $1 / 30 / 04$ & 181.7 & 121.7 & 120.0 \\
\hline VEW-03A & 70 & 4 & 122.0 & $1 / 20 / 04$ & 122.0 & 92.0 & 89.5 \\
\hline VEW-04A & 35 & 4 & 200.5 & $10 / 29 / 03$ & 200.0 & 155.3 & 150.0 \\
\hline VEW-05A & 60 & 4 & 187.0 & $12 / 15 / 03$ & 178.0 & 128.0 & 125.0 \\
\hline VEW-06A & 49 & 4 & 210.0 & $11 / 13 / 03$ & 207.0 & 147.0 & 143.0 \\
\hline VEW-07F & 90 & 6 & 159.0 & $10 / 28 / 03$ & 157.0 & 37.0 & 33.4 \\
\hline VEW-08A & 70 & 4 & 122.0 & $12 / 2 / 03$ & 122.0 & 92.0 & 89.0 \\
\hline VEW-09A & 61 & 4 & 186.5 & $12 / 8 / 03$ & 181.5 & 131.5 & 129.0 \\
\hline VEW-10A & 35 & 4 & 200.5 & $10 / 20 / 03$ & 200.5 & 154.0 & 150.0 \\
\hline VEW-11F & 90 & 6 & 160.0 & $7 / 17 / 03$ & 155.0 & 35.0 & 32.7 \\
\hline VEW-12A & 41 & 4 & 247.0 & $10 / 9 / 03$ & 243.0 & 170.0 & 166.0 \\
\hline VEW-13A & 70 & 4 & 122.0 & 9/8/03 & 122.0 & 95.0 & 93.2 \\
\hline VEW-14A & 60 & 4 & 180.2 & $9 / 2 / 03$ & 180.2 & 130.2 & 128.0 \\
\hline VEW-15A & 33 & 4 & 200.5 & $8 / 20 / 03$ & 190.1 & 143.0 & 141.5 \\
\hline VEW-16F & 90 & 6 & 157.0 & $10 / 23 / 03$ & 155.0 & 34.9 & 32.2 \\
\hline VEW-17A & 39 & 4 & 246.0 & $8 / 6 / 03$ & 243.0 & 169.7 & 163.0 \\
\hline VEW-18A & 70 & 4 & 122.0 & $7 / 28 / 03$ & 122.0 & 94.6 & 91.9 \\
\hline VEW-19A & 60 & 4 & 186.0 & $7 / 22 / 03$ & 182.0 & 129.5 & 126.0 \\
\hline VEW-20F & 90 & 6 & 157.0 & $10 / 30 / 03$ & 153.0 & 33.0 & 30.6 \\
\hline VEW-21F & 90 & 6 & 155.0 & 9/29/03 & 152.0 & 32.1 & 28.5 \\
\hline VEW-22A & 0 & 4 & $56.0 \max$ & $1 / 30 / 04$ & NA & NA & NA \\
\hline VEW-23F & 90 & 6 & 155.0 & $9 / 15 / 03$ & 148.0 & 28.0 & 27.0 \\
\hline VEW-24A & 25 & 4 & 212.0 & $12 / 22 / 03$ & 212.0 & 139.0 & 136.5 \\
\hline VEW-25A & 25 & 4 & 212.0 & $10 / 23 / 03$ & 212.0 & 139.0 & 133.0 \\
\hline VEW-26F & 90 & 6 & 158.0 & $10 / 2 / 03$ & 157.0 & 37.0 & 35.1 \\
\hline VEW-27A & 27 & 4 & 212.0 & $8 / 13 / 03$ & 212.0 & 140.2 & 140.2 \\
\hline VEW-28F & 90 & 6 & 162.0 & $11 / 4 / 03$ & 161.0 & 41.0 & 39.0 \\
\hline VEW-29F & 90 & 6 & 160.0 & $10 / 7 / 03$ & 160.0 & 40.0 & 38.1 \\
\hline VEW-30F & 90 & 6 & 167.0 & $10 / 13 / 03$ & 160.5 & 40.4 & 37.3 \\
\hline VEW-31F & 90 & 6 & 166.0 & $10 / 21 / 03$ & 166.0 & 45.8 & 43.6 \\
\hline VEW-32F & 90 & 6 & 152.0 & $9 / 17 / 03$ & 152.0 & 32.0 & 28.7 \\
\hline VEW-33F & 90 & 6 & 150.0 & $8 / 20 / 03$ & 147.6 & 27.6 & 25.3 \\
\hline VEW-34F & 90 & 6 & 160.0 & $2 / 25 / 04$ & 160.0 & 39.9 & 36.4 \\
\hline
\end{tabular}

Note: Wells VEW-13A, VEW16F, and VEW-32F were not tested. See text for additional details. 
SRNL-STI-2013-00039

Revision 0

Table 2: Identification of Vapor Extraction Wells in Each Parcel of the WSTS

\begin{tabular}{|c|c|c|c|}
\hline Parcel 1 & Parcel 2 & Parcel 3 & Parcel 4 \\
\hline VEW24A & VEW01F & VEW12A & VEW20F \\
\hline VEW25A & VEW02A & VEW13A & VEW22A \\
\hline VEW28F & VEW03A & VEW14A & VEW33F \\
\hline VEW29F & VEW04A & VEW15A & VEW23F \\
\hline VEW30F & VEW05A & VEW17A & VEW32F \\
\hline VEW31F & VEW06A & VEW18A & VEW21F \\
\hline VEW34F & VEW07F & VEW19A & \\
\hline & VEW08A & VEW26F & \\
\hline & VEW09A & VEW27A & \\
\hline & VEW10A & VEW16A & \\
\hline & VEW11A & & \\
\hline
\end{tabular}

Table 3: Extraction Wells and Data Used to Estimate Flow Rates using Inverse Distance Weighting Methods

\begin{tabular}{|l|c|r|r|c|}
\hline \multirow{2}{*}{ Well ID } & \multirow{2}{*}{$\begin{array}{c}\text { Flow } \\
\text { (cfm) }\end{array}$} & \multicolumn{3}{|c|}{ Distance From Well (meters) } \\
\cline { 3 - 5 } & VEW-21F & VEW-23F & VEW-31F \\
\hline VEW-33F & 82 & 42.4 & 28.4 & 178.3 \\
\hline VEW-34F & 86 & 108.3 & 133.1 & 35.9 \\
\hline VEW-29F & 100 & 92.1 & 112.9 & 44.5 \\
\hline VEW-26F & 151 & 62.0 & 83.1 & 74.7 \\
\hline VEW-30F & 178 & 113.0 & 133.4 & 24.1 \\
\hline VEW-11F & 294 & 66.6 & 80.8 & 78.9 \\
\hline VEW-20F & 313 & 17.6 & 47.1 & 120.8 \\
\hline VEW-01F & 324 & 115.7 & 127.3 & 55.4 \\
\hline VEW-28F & 358 & 110.7 & 127.1 & 37.7 \\
\hline VEW-07F & 371 & 78.3 & 90.5 & 73.9 \\
\hline \multicolumn{5}{|l|}{} \\
\hline Estimated Flow (cfm) & 269 & 173 & 204 \\
\hline
\end{tabular}

Note: Estimated results based upon inverse distance exponent of 2 (Isaaks and Srivastave 1989). 
SRNL-STI-2013-00039

Revision 0

Table 4: Best Estimate of Vapor Conditions from DUS-II Vapor Extraction Wells ${ }^{1}$.

\begin{tabular}{|c|c|c|c|c|c|c|}
\hline $\begin{array}{l}\text { Well } \\
\text { Name }\end{array}$ & $\begin{array}{c}\text { Temperature } \\
\left({ }^{\circ} \mathrm{F}\right)\end{array}$ & $\begin{array}{c}\text { Vacuum } \\
\text { (InHg) }\end{array}$ & $\begin{array}{l}\text { Average } \\
\text { Flow (cfm) }\end{array}$ & $\begin{array}{c}\text { PCE } \\
(\mathrm{mg} / \mathrm{m} 3)\end{array}$ & $\begin{array}{c}\text { TCE } \\
(\mathrm{mg} / \mathrm{m} 3)\end{array}$ & $\begin{array}{l}111-T C A \\
(\mathrm{mg} / \mathrm{m} 3)\end{array}$ \\
\hline VEW-01F & 135 & 6.6 & 324 & 20.18 & 4.64 & - \\
\hline VEW-02A & 147 & 4.8 & 288 & 3.20 & 1.45 & - \\
\hline VEW-03A & 143 & 6.7 & 210 & 8.76 & 3.40 & - \\
\hline VEW-04A & 130 & 5.8 & 204 & 3.91 & 2.06 & - \\
\hline VEW-05A & 148 & 6.5 & 248 & 6.43 & 4.95 & - \\
\hline VEW-06A & 142 & 6.0 & 100 & 11.98 & 2.35 & - \\
\hline VEW-07F & 151 & 5.3 & 371 & 102.2 & 18.8 & - \\
\hline VEW-08A & 149 & 5.0 & 88 & 12.43 & 6.8 & - \\
\hline VEW-09A & 158 & 4.9 & 181 & 2.00 & - & - \\
\hline VEW-10A & 130 & 5.0 & 156 & 7.09 & 4.03 & - \\
\hline VEW-11F & 144 & 4.9 & 294 & 80.2 & 14.27 & - \\
\hline VEW-12A & 137 & 5.7 & 300 & 1.22 & - & - \\
\hline VEW-14A & 150 & 4.3 & 124 & 3.28 & 0.62 & - \\
\hline VEW-15A & 129 & 6.3 & 293 & 4.02 & 3.09 & - \\
\hline VEW-17A & 126 & 5.5 & 248 & 1.86 & - & - \\
\hline VEW-18A & 127 & 7.3 & 96 & 0.78 & - & - \\
\hline VEW-19A & 98 & 7.4 & 4 & 6.00 & 1.54 & - \\
\hline VEW-20F & 103 & 5.6 & 313 & 0.78 & - & - \\
\hline VEW-21F & 126 & 4.1 & $269(2)$ & 1.62 & 0.62 & - \\
\hline VEW-22A & 87 & 5.1 & 238 & 547.6 & 326.8 & - \\
\hline VEW-23F & 101 & 5.5 & $173(2)$ & 30.5 & 12.1 & - \\
\hline VEW-24A & 116 & 6.1 & 183 & 91.6 & 5.41 & - \\
\hline VEW-25A & 136 & 5.6 & 434 & 78.51 & 33.76 & - \\
\hline VEW-26F & 140 & 7.4 & 151 & 131.56 & 6.17 & - \\
\hline VEW-27A & 105 & 5.8 & 5 & 11.91 & 10.53 & - \\
\hline VEW-28F & 147 & 4.8 & 358 & 33.28 & 6.21 & - \\
\hline VEW-29F & 139 & 5.4 & 100 & 290.88 & 6.71 & - \\
\hline VEW-30F & 141 & 4.5 & 178 & 207.13 & 7.45 & - \\
\hline VEW-31F & 107 & 4.6 & $204(2)$ & 129.45 & 6.21 & - \\
\hline VEW-33F & 88 & 4.8 & 82 & 3.98 & - & - \\
\hline VEW-34F & 100 & 5.7 & 86 & 18.86 & 2.48 & - \\
\hline
\end{tabular}

Notes:

(1) Conditions based upon observations in June 2012 (Noonkester et al., 2012)

(2) Flow was estimated for VEW-21F, VEW-23F, and VEW-31F. (See section 3.1 for details). 
SRNL-STI-2013-00039

Revision 0

Table 5: Estimated Extraction Rate of Individual Vapor Extraction Wells at MASB ${ }^{1}$

\begin{tabular}{|c||c|c|c||c||c||}
\hline $\begin{array}{c}\text { Well } \\
\text { Name }\end{array}$ & $\begin{array}{c}\text { PCE } \\
\text { (Ibs/day) }\end{array}$ & $\begin{array}{c}\text { TCE } \\
\text { (Ibs/day) }\end{array}$ & $\begin{array}{c}\text { 111-TCA } \\
\text { (Ibs/day) }\end{array}$ & $\begin{array}{c}\text { Total VOC } \\
\text { (lbs/day) }\end{array}$ & Rank \\
\hline VEW-01F & 0.588 & 0.135 & - & 0.724 & 11 \\
\hline VEW-02A & 0.083 & 0.037 & - & 0.120 & 20 \\
\hline VEW-03A & 0.165 & 0.064 & - & 0.230 & 14 \\
\hline VEW-04A & 0.072 & 0.038 & - & 0.110 & 21 \\
\hline VEW-05A & 0.143 & 0.110 & - & 0.254 & 13 \\
\hline VEW-06A & 0.107 & 0.021 & - & 0.129 & 19 \\
\hline VEW-07F & 3.409 & 0.628 & - & 4.037 & 3 \\
\hline VEW-08A & 0.098 & 0.054 & - & 0.152 & 18 \\
\hline VEW-09A & 0.033 & - & - & 0.033 & 26 \\
\hline VEW-10A & 0.099 & 0.056 & - & 0.156 & 17 \\
\hline VEW-11F & 2.116 & 0.377 & - & 2.493 & 6 \\
\hline VEW-12A & 0.033 & - & - & 0.033 & 25 \\
\hline VEW-14A & 0.037 & 0.007 & - & 0.044 & 23 \\
\hline VEW-15A & 0.106 & 0.081 & - & 0.187 & 15 \\
\hline VEW-17A & 0.042 & - & - & 0.042 & 24 \\
\hline VEW-18A & 0.007 & - & - & 0.007 & 30 \\
\hline VEW-19A & 0.002 & 0.001 & - & 0.003 & 31 \\
\hline VEW-20F & 0.022 & - & - & 0.022 & 28 \\
\hline VEW-21F & 0.039 & 0.015 & - & 0.054 & 22 \\
\hline VEW-22A & 11.715 & 6.992 & - & 18.708 & 1 \\
\hline VEW-23F & 0.474 & 0.188 & - & 0.662 & 12 \\
\hline VEW-24A & 1.511 & 0.089 & - & 1.600 & 9 \\
\hline VEW-25A & 3.064 & 1.318 & - & 4.382 & 2 \\
\hline VEW-26F & 1.780 & 0.083 & - & 1.863 & 8 \\
\hline VEW-27A & 0.005 & 0.005 & - & 0.010 & 29 \\
\hline VEW-28F & 1.070 & 0.199 & - & 1.269 & 10 \\
\hline VEW-29F & 2.615 & 0.060 & - & 2.675 & 5 \\
\hline VEW-30F & 3.314 & 0.119 & - & 3.434 & 4 \\
\hline VEW-31F & 2.374 & 0.114 & - & 2.488 & 7 \\
\hline VEW-33F & 0.029 & - & - & 0.029 & 27 \\
\hline VEW-34F & 0.146 & 0.019 & - & 0.165 & 16 \\
\hline \hline
\end{tabular}

Notes:

(1) Performance based upon Best Estimate of Conditions presented in Table 4.

(2) Extraction Rates for VEW-21F, VEW-23F, and VEW-31F based upon estimated flow data (see Section 3.1 for details). 
Table 6: Groupings of Extraction Wells Based on Extraction Rates

\begin{tabular}{||c||c|c|c||c||c||}
\hline Well Name & $\begin{array}{c}\text { PCE } \\
\text { (lbs/day) }\end{array}$ & $\begin{array}{c}\text { TCE } \\
\text { (lbs/day) }\end{array}$ & $\begin{array}{c}\text { 111-TCA } \\
\text { (lbs/day) }\end{array}$ & $\begin{array}{c}\text { Total VOC } \\
\text { (lbs/day) }\end{array}$ & Rank \\
\hline VEW-22A & 11.715 & 6.992 & - & 18.708 & 1 \\
\hline
\end{tabular}

Group 1: Wells Recommended for Continued SVE Operation (n=9).

\begin{tabular}{||c||c|c|c||c||c||}
\hline VEW-25A & 3.064 & 1.318 & - & 4.382 & 2 \\
\hline VEW-07F & 3.409 & 0.628 & - & 4.037 & 3 \\
\hline VEW-30F & 3.314 & 0.119 & - & 3.434 & 4 \\
\hline VEW-29F & 2.615 & 0.060 & - & 2.675 & 5 \\
\hline VEW-11F & 2.116 & 0.377 & - & 2.493 & 6 \\
\hline VEW-31F (a) & 2.374 & 0.114 & - & 2.488 & 7 \\
\hline VEW-26F & 1.780 & 0.083 & - & 1.863 & 8 \\
\hline VEW-24A & 1.511 & 0.089 & - & 1.600 & 9 \\
\hline VEW-28F & 1.070 & 0.199 & - & 1.269 & 10 \\
\hline
\end{tabular}

Group 2: Wells Proposed for Transition to Passive Vapor Extraction (n=11).

\begin{tabular}{||c||c|c|c||c||c||}
\hline VEW-01F & 0.588 & 0.135 & - & 0.724 & 11 \\
\hline VEW-23F (a) & 0.474 & 0.188 & - & 0.662 & 12 \\
\hline VEW-05A & 0.143 & 0.110 & - & 0.254 & 13 \\
\hline VEW-03A & 0.165 & 0.064 & - & 0.230 & 14 \\
\hline VEW-15A & 0.106 & 0.081 & - & 0.187 & 15 \\
\hline VEW-34F & 0.146 & 0.019 & - & 0.165 & 16 \\
\hline VEW-10A & 0.099 & 0.056 & - & 0.156 & 17 \\
\hline VEW-08A & 0.098 & 0.054 & - & 0.152 & 18 \\
\hline VEW-06A & 0.107 & 0.021 & - & 0.129 & 19 \\
\hline VEW-02A & 0.083 & 0.037 & - & 0.120 & 20 \\
\hline VEW-04A & 0.072 & 0.038 & - & 0.110 & 21 \\
\hline
\end{tabular}

Group 3: Wells that have Minimal Mass Extraction Rates $(\mathbf{n}=10)$.

\begin{tabular}{||c||c|c|c||c||c||}
\hline VEW-21F $(\mathrm{a}, \mathrm{b})$ & 0.039 & 0.015 & - & 0.054 & 22 \\
\hline VEW-14A & 0.037 & 0.007 & - & 0.044 & 23 \\
\hline VEW-17A & 0.042 & - & - & 0.042 & 24 \\
\hline VEW-12A & 0.033 & - & - & 0.033 & 25 \\
\hline VEW-09A & 0.033 & - & - & 0.033 & 26 \\
\hline VEW-33F (b) & 0.029 & - & - & 0.029 & 27 \\
\hline VEW-20F & 0.022 & - & - & 0.022 & 28 \\
\hline VEW-27A & 0.005 & 0.005 & - & 0.010 & 29 \\
\hline VEW-18A & 0.007 & - & - & 0.007 & 30 \\
\hline VEW-19A & 0.002 & 0.001 & - & 0.003 & 31 \\
\hline
\end{tabular}

(a) Extraction Rates estimated for VEW-21F, VEW-23F, and VEW-31F (see Section 3.1 for details).

(b) Extraction well VEW-21F and VEW-33F are dual extraction (groundwater and vapor) wells. 
SRNL-STI-2013-00039

Revision 0

Table 7: Estimated Performance of Group 2 Vapor Extraction Wells Using MicroBlower $^{\mathrm{TM}}$ Technology $^{1}$

\begin{tabular}{||c||c|c|c||c||}
\hline Well Name & $\begin{array}{c}\text { PCE } \\
\text { (Ibs/day) }\end{array}$ & $\begin{array}{c}\text { TCE } \\
\text { (lbs/day) }\end{array}$ & $\begin{array}{c}\text { 111-TCA } \\
\text { (lbs/day) }\end{array}$ & $\begin{array}{c}\text { Total VOC } \\
\text { (lbs/day) }\end{array}$ \\
\hline VEW-01F & 0.018 & 0.004 & - & 0.022 \\
\hline VEW-02A & 0.003 & 0.001 & - & 0.004 \\
\hline VEW-03A & 0.008 & 0.003 & - & 0.011 \\
\hline VEW-04A & 0.004 & 0.002 & - & 0.005 \\
\hline VEW-05A & 0.006 & 0.004 & - & 0.010 \\
\hline VEW-06A & 0.011 & 0.002 & - & 0.013 \\
\hline VEW-08A & 0.011 & 0.006 & - & 0.017 \\
\hline VEW-10A & 0.006 & 0.004 & - & 0.010 \\
\hline VEW-15A & 0.004 & 0.003 & - & 0.006 \\
\hline VEW-23F & 0.027 & 0.011 & - & 0.038 \\
\hline VEW-34F & 0.017 & 0.002 & - & 0.019 \\
\hline \hline
\end{tabular}

Note:

(1) Performance based upon Best Estimate of Conditions presented in Table 4 and 24-Volt Microblower System at $10 \mathrm{cfm}$.

Table 8: Vapor Extraction Wells that are Recemmended for Abandonment $(n=11)$

\begin{tabular}{|c|l|}
\hline Well ID & \multicolumn{1}{c|}{ Basis for Abandonment } \\
\hline VEW-09A & Extraction rate $<0.1$ pound per day using active extraction system. \\
\hline VEW-12A & Extraction rate $<0.1$ pound per day using active extraction system. \\
\hline VEW-13A & Poor performance based upon 2009 sampling results. \\
\hline VEW-14A & Extraction rate $<0.1$ pound per day using active extraction system. \\
\hline VEW-16F & No longer connected to active extraction system. \\
\hline VEW-17A & Extraction rate $<0.1$ pound per day using active extraction system. \\
\hline VEW-18A & Extraction rate $<0.1$ pound per day using active extraction system. \\
\hline VEW-19A & Extraction rate $<0.1$ pound per day using active extraction system. \\
\hline VEW-20F & Extraction rate $<0.1$ pound per day using active extraction system. \\
\hline VEW-27A & Extraction rate $<0.1$ pound per day using active extraction system. \\
\hline VEW-32F & No longer connected to active extraction system. \\
\hline
\end{tabular}


SRNL-STI-2013-00039

Revision 0

\subsection{APPENDIX}

Fall 2009 Wellhead Results for DUS Extraction Wells (from DUS System Engineer files)

\begin{tabular}{||c||c|c|c||}
\hline Well Name & $\begin{array}{c}\text { PCE } \\
\text { (ppmv) }\end{array}$ & $\begin{array}{c}\text { TCE } \\
\text { (ppmv) }\end{array}$ & $\begin{array}{c}\text { TCA } \\
\text { (ppmv) }\end{array}$ \\
\hline VEW-01F & 98 & 21 & 7 \\
\hline VEW-02A & 170 & 24 & 4 \\
\hline VEW-03A & 22 & 5 & 1 \\
\hline VEW-04A & 11 & 3 & 0 \\
\hline VEW-05A & 2 & 2 & 0 \\
\hline VEW-06A & 152 & 26 & 11 \\
\hline VEW-07F & 86 & 12 & 11 \\
\hline VEW-08A & 23 & 5 & 1 \\
\hline VEW-09A & 224 & 20 & 11 \\
\hline VEW-10A & 15 & 4 & 0 \\
\hline VEW-11F & 25 & 6 & 3 \\
\hline VEW-12A & 1 & 2 & 0 \\
\hline VEW-13A & 3 & 2 & 0 \\
\hline VEW-14A & 4 & 3 & 0 \\
\hline VEW-15A & 4 & 2 & 0 \\
\hline VEW-17A & 2 & 2 & 0 \\
\hline VEW-18A & 398 & 28 & 7 \\
\hline VEW-19A & 7 & 3 & 1 \\
\hline VEW-20F & 289 & 19 & 4 \\
\hline VEW-22A & 46 & 11 & 0 \\
\hline VEW-24A & 14 & 4 & 1 \\
\hline VEW-25A & 15 & 4 & 0 \\
\hline VEW-26F & 42 & 6 & 2 \\
\hline VEW-27A & 4 & 3 & 0 \\
\hline VEW-28F & 11 & 3 & 0 \\
\hline VEW-29F & 41 & 7 & 2 \\
\hline VEW-30F & & 38 & 9 \\
\hline VEW-31F & 90 & 9 & 2 \\
\hline VEW-34F & 25 & 4 & 1 \\
\hline \hline
\end{tabular}

Note: No results reported for VEW-16F, VEW-21F, VEW-23F, VEW-32F, or VEW-33F. 